Sains Malaysiana 50(9)(2021): 2653-2661

http://doi.org/10.17576/jsm-2021-5009-13

\title{
Prosedur Pengekstrakan untuk Analisis Logam Berat dalam Tisu Tumbuhan dan Persekitaran Hevea brasiliensis
}

(Extraction Procedures for Heavy Metals Analysis in Plant Tissues and Surrounding Soils of Hevea brasiliensis)

\author{
Muhammad Jefri Mohd Yusof, Mohd Talib Latif \& Siti Fairus Mohd YusofF*
}

\begin{abstract}
ABSTRAK
Pengukuran logam berat dalam sampel tumbuhan berguna untuk menunjukkan kualiti udara persekitaran yang diserap. Walau bagaimanapun, ikatan logam berat dengan matriks organik memerlukan kaedah pengekstrakan yang sesuai untuk melepaskannya kerana cara penjerapan yang berbeza mengikut sampel. Dalam kajian ini, kami meneroka beberapa kaedah pengekstrakan untuk menghasilkan kepekatan logam berat yang maksimum dalam sampel pokok Hevea brasiliensis dan tanah sekitarnya di Bentong, Pahang, Malaysia. Pengesktrakan yang maksimum adalah penting untuk memberikan maklumat analisis logam berat yang sebenar. Rendaman sejuk, pengekstrakan ultrasonik, pencernaan gelombang mikro, teknik pengeringan abu dan pencernaan asid panas dilakukan dan dibandingkan dengan analisis logam berat dalam sampel tanah, daun, kulit pokok dan lateks. Seterusnya, kandungan logam berat tersebut dikuantifikasi menggunakan spektrofotometer pancaran plasma-gandingan aruhan (ICP-OES). Hasilnya, setiap sampel didapati memerlukan kaedah pencernaan yang eksklusif untuk mengekstrak logam berat dengan jumlah tertinggi. Teknik pencernaan asid panas dan pengeringan abu adalah kaedah pencernaan yang paling sesuai, masing-masing untuk tanah dan getah, manakala pencernaan gelombang mikro mengekstrak logam paling berat dalam sampel daun dan kulit pokok. Antara semua sampel tanaman, daun memerangkap paling banyak logam paling berat (767.4 mg/kg) diikuti oleh kulit kayu (600.2 $\mathrm{mg} / \mathrm{kg})$ dan lateks $(185.4 \mathrm{mg} / \mathrm{kg})$. Analisis logam berat melaporkan nilai faktor pengayaan (EF) logam berat yang tinggi $(E F>10)$ menerangkan kepekatan logam berat yang tinggi dalam setiap sampel. Selain itu, pengiraan faktor biokepekatan (BCF) membuktikan bahawa logam berat dalam sampel datang daripada sampel tanah melalui sistem akar pokok apabila nilai $B C F>1$.
\end{abstract}

Kata kunci: Biomonitor; Hevea brasiliensis; logam berat; pencernaan asid; pengekstrakan

\section{ABSTRACT}

The quantification of heavy metals in plant's samples is useful to imply the quality of environmental air that is being absorbed. However, the binding of heavy metals with organic matrices requires suitable extraction method to leach them apart due to different adsorption manners. In this study, we explored several extraction methods to yield maximum concentrations of heavy metals in plant samples of Hevea brasiliensis and its surrounding soils in Bentong, Pahang, Malaysia. This is crucial to obtain precise output for heavy metals analysis. Maceration, ultrasonic extraction, acid-assisted microwave digestion, ash drying technique, and hot acid digestion were performed and compared on our heavy metals analysis in soils, leaves, tree barks and latex. Next, the heavy metals contents in those samples were quantified using inductively coupled plasma optical emission spectroscopy (ICP-OES). As a result, each sample demanded their exclusive digestion method to extract the highest amounts of heavy metals. Hot acid digestion and ash drying technique were the most suitable digestion method for soils and latex, respectively, whereby, microwave-assisted acid digestion extracted the most heavy metals in both leaves and tree barks. Of all plant samples, leaves trapped the most heavy metals $(767.4 \mathrm{mg} / \mathrm{kg}$ ) followed by tree barks $(600.2 \mathrm{mg} / \mathrm{kg})$ and latex $(185.4 \mathrm{mg} / \mathrm{kg})$. High enrichment factor, $E F(E F>10)$ justified the increased heavy metals in each sample. Besides, bioconcentration factor (BCF) with the value above 1 proved that the heavy metals in plant's samples were up took from soils via root system.

Keywords: Acid digestion; biomonitoring; extraction; heavy metals; Hevea brasiliensis 


\section{Pengenalan}

Logam berat boleh hadir di persekitaran melalui sumber semula jadi (sumber mineral, hakisan dan aktiviti gunung berapi) atau antropogenik (perlombongan, baja, racun perosak, asap kilang dan pelepasan asap kenderaan (Selvi et al. 2019)). Logam surih dalam bentuk semula jadi wujud sebagai spesies yang tidak bergerak di tanah yang tidak tercemar dan terikat pada silikat dan mineral utama. Di kawasan tanah yang tercemar, logam berat dijumpai dalam fasa sedimen dan mudah didapati dalam fasa bergerak, oleh itu, dapat memasuki sistem fisiologi tumbuhan dengan mudah (Ayaz et al. 2014; Witters et al. 2011). Bahagian tumbuhan seperti daun dan kulit kayu yang terdedah kepada bahan kimia persekitaran, adalah salah satu laluan bahan pencemar ini (Rajkumar et al. 2012).

Logam berat dapat dikelaskan kepada peranan penting dan tidak penting dalam sistem biologi. Logam berat penting diperlukan untuk pertumbuhan dan kemajuan tanaman dalam fungsi biokimia dan fisiologi (Wei et al. 2020). Sebagai contoh, Fe, Mn, Cu, Zn dan Ni diperlukan dalam jumlah yang kecil untuk aktiviti metabolik (Thakur et al. 2016). Apabila melebihi nilai ambang toleransi logam berat, laluan sel dan enzim tanaman mungkin terganggu dengan kepekatan logam berat yang tinggi (Chibuike \& Obiora 2014). Sementara itu, logam berat tidak penting seperti $\mathrm{Pb}, \mathrm{As}, \mathrm{Cd}$ dan $\mathrm{Cr}$ tidak mempunyai peranan yang khusus dan boleh menyebabkan tekanan oksidatif dalam sistem pokok. Pengumpulan logam berat ini di dalam tanah dan tisu tumbuhan, setelah diekstrak, berguna untuk menunjukkan kualiti persekitaran dan menilai kemampuan sesuatu spesies organisma dalam mengurangkan pencemaran (Li et al. 2014).

Secara amnya, logam berat larut dalam asid lemah atau kuat (Ricci et al. 2016). Medium berasid membantu memutuskan ikatan ion antara logam berat dan matriks. Selain itu, logam hanya dapat dikesan menggunakan spektrometer dalam larutan akues berasid dengan $\mathrm{pH} 5.5$ atau lebih rendah (Yilmaz et al. 2014). Rauret (1998) mengkaji bahawa asid yang paling biasa digunakan dalam pengekstrakan logam berat ialah $\mathrm{HNO}_{3} \mathrm{HCl}, \mathrm{CH}_{3} \mathrm{COOH}$ dan $\mathrm{H}_{2} \mathrm{SO}_{4}$. Seperti yang dilaporkan oleh kebanyakan penyelidik, $\mathrm{HNO}_{3}$ sering digunakan kerana tahap pemulihan dan pengekstrakan logamnya yang tinggi (Melo et al. 2016). Semasa pengekstrakan, $\mathrm{HNO}_{3}$ boleh bertindak sebagai kedua-dua agen asid dan pengoksidaan (de Mello et al. 2020).
Beberapa kajian turut melaporkan mengenai gabungan asid-asid untuk mengekstrak logam berat dalam bentuk larutan (Melo et al. 2016; Zimmerman \& Weindorf 2010). Walau bagaimanapun, gabungan $\mathrm{HCI}$ dan $\mathrm{H}_{2} \mathrm{SO}_{4}$ akan membentuk produk sampingan yang tidak larut semasa pencernaan asid sehingga menurunkan jumlah logam berat yang diekstrak (de Mello et al. 2020). Didapati penggunaan $\mathrm{HNO}_{3}$ pekat sahaja sudah mencukupi untuk mencerna logam berat. Hseu (2004) menilai kandungan logam berat dalam sembilan kompos dan mengesyorkan prosedur $\mathrm{HNO}_{3}$ berdasarkan analisis pemulihan, masa reaksi dan penjimatan kos.

Teknik pengekstrakan harus dikembangkan sebelum jenis sampel atau matriks dicerna. Antara faktor yang perlu dipertimbangkan ketika menggunakan prosedur pengekstrakan termasuk penggunaan masa dan bahan kimia, kerja makmal dan hasil (Ahmed 2009; Trusheva et al. 2007). Kaya dan Yaman (2012) membandingkan pengeringan abu dan pencernaan gelombang mikro dalam menentukan logam surih dalam daun Platanus sp.

Mereka tidak menemui perbezaan kepekatan logam surih yang signifikan untuk kedua-dua kaedah tersebut tetapi lebih memilih teknik pengeringan abu kerana lebih mudah dan menggunakan reagen yang minimum. Singh et al. (2016) melaporkan mengenai pengekstrakan logam berat daripada metilena biru menggunakan pencernaan asid dibantu ultrasonik. Mereka berjaya mengekstrak logam berat daripada larutan metilena biru pada suhu bilik $\left(25^{\circ} \mathrm{C}\right)$. Untuk teknik pencernaan asid panas, Factory et al. (2016) membuktikan bahawa kaedah ini dapat mengekstrak logam berat daripada sampel tanaman. Mereka melaporkan bioakumulasi $\mathrm{Cd}$ dan $\mathrm{Zn}$ yang tinggi dalam tanah yang sedikit tinggi daripada had yang dibenarkan WHO. Sementara itu, Kleckerová dan Dočekalová (2014) merendam sejuk tanah mereka selama 16 jam dan melakukan teknik pencernaan gelombang mikro untuk mengukur tahap kandungan logam berat dalam akar dan daun pokok dandelion di beberapa kawasan berbeza. Mereka mendapati corak pencemaran logam berat yang sepadan dengan lokasi persampelan mengikut tahap pencemaran, menjadikan tumbuhan dandelion sebagai biomonitor yang baik di kawasan bandar.

Dalam kajian ini, kami ingin menentukan kaedah pencernaan terbaik untuk sampel tanah, daun, kulit pokok dan lateks. Beberapa teknik pencernaan telah dilakukan untuk mengekstrak logam berat daripada 
sampel tersebut. Maklumat ini sangat berguna dalam merancang prosedur pengekstrakan logam berat yang maksimum berdasarkan sampel tumbuhan pada masa akan datang. Di samping itu, nilai maksimum kandungan logam berat ini adalah penting bagi menunjukkan tahap serapan logam berat yang sebenar oleh tumbuhan (Rashid et al. 2016).

\section{BAHAN DAN KAEDAH}

\section{PENSAMPELAN}

Lokasi kajian ini adalah di kampung Simpang Pelangai, Bentong, Pahang (3.1136 $\left.\mathrm{U}, 102.1448^{\circ} \mathrm{T}\right)$ yang merupakan kawasan luar bandar pada bulan Februari 2017. Sampel tanah, daun, kulit kayu dan lateks diambil untuk dianalisis. Bagi memastikan tiada pencemaran silang berlaku pada sampel, pensampelan dilakukan mengikut prosedur yang dianjurkan oleh Simpson (2017) berdasarkan ketetapan oleh U.S Environmental Protection Agency (EPA). Sampel tersebut diambil secara rawak di kawasan tepi jalan raya. Semua sampel disimpan di dalam peti ais dengan suhu $-5{ }^{\circ} \mathrm{C}$ sebelum analisis seterusnya. Sampel untuk analisis dikeringkan terlebih dahulu di dalam relau pada suhu $50^{\circ} \mathrm{C}$ selama 24 jam sebelum diproses.

\section{SAMPEL TANAH}

Sampel tanah dikorek $5 \mathrm{~cm}$ daripada permukaan tanah menggunakan penyodok tangan sebelum disimpan di dalam beg plastik polietilin. Sampel dikeringkan di dalam relau kemudian diayak menggunakan pengayak $25 \mathrm{~mm}$ dan penggoncang ayak dengan kelajuan $0.35 \mathrm{~cm} /$ $\mathrm{m}^{2}$ selama 30 minit hingga 1 jam. Sampel tanah dalam bentuk debu halus tersebut disimpan dalam bekas plastik dan sedia untuk dicernakan.

\section{SAMPEL DAUN}

Lebih kurang 50 helai daun dewasa pada dahan pertama pokok getah pada ketinggian 1.5 - 2 meter dari tanah diambil menggunakan gunting besi dan disimpan dalam beg kertas untuk dibawa ke makmal. Sampel daun tersebut dibersihkan dengan air ternyahion kemudian dikeringkan di dalam relau. Kemudian, daun tersebut dikisar dengan pengisar kering menjadi cebisan kecil daun dan seterusnya disimpan dalam bekas plastik untuk analisis seterusnya.

\section{SAMPEL KULIT KAYU}

Tukul dan pengumpil digunakan bagi mendapatkan sampel kulit kayu batang pokok pada jarak 1 meter dari tanah dengan saiz $5 \times 5 \mathrm{~cm}^{2}$ dengan kedalaman $2 \mathrm{~mm}$. Sampel disimpan dalam beg kertas sebelum dikeringkan di dalam relau. Seterusnya, sampel dikisar dengan pengisar kering menjadi serbuk halus dan disimpan dalam bekas plastik untuk dicernakan.

\section{SAMPEL LATEKS}

Lateks atau susu getah daripada pokok getah diperoleh dengan cara torehan tradisional iaitu menggunakan pisau pemotong pokok getah menggunakan sistem ibidiem atau juga dikenali sebagai sistem tulang ikan hering pada waktu pagi. Lateks yang mengalir daripada batang pokok getah ditadah dalam mangkuk plastik dan digumpalkan menjadi pepejal dengan menambahkan $10 \mathrm{~mL}$ asid formik. Sampel ini disimpan dalam beg plastik dan seterusnya dikeringkan di dalam relau sebelum analisis seterusnya dijalankan.

\section{PROSEDUR PENGEKSTRAKAN LOGAM BERAT}

Perbandingan kaedah-kaedah pencernaan asid telah dijalankan bagi menentukan kaedah terbaik untuk mengekstrak jumlah logam berat terbanyak dalam setiap sampel. Antara kaedah yang digunakan ialah:

\section{MIKROGELOMBANG}

Sampel sebanyak $0.5 \mathrm{~g}$ ditimbang dan dimasukkan ke dalam botol Teflon yang mengandungi $5 \mathrm{~mL}$ asid nitrik pekat. Sampel dipanaskan di dalam ketuhar gelombang mikro dengan tetapan $500 \mathrm{~W}$ selama 5 minit. Sampel kemudian dibiarkan sejuk pada suhu bilik $\left(28^{\circ} \mathrm{C}\right)$ dan seterusnya dituras menggunakan sistem pam vakum dan dicairkan hingga $100 \mathrm{~mL}$. Sebanyak $10 \mathrm{~mL}$ sampel diperlukan untuk analisis logam berat (Liu et al. 2014).

\section{PENCERNAAN ASID PANAS}

Sebanyak $0.5 \mathrm{~g}$ sampel ditimbang dalam bikar $50 \mathrm{~mL}$. Asid nitrik pekat sebanyak $5 \mathrm{~mL}$ dicampurkan dan larutan tersebut dipanaskan hingga mendidih selama 15 minit. Kemudian, larutan tersebut dibiarkan sejuk pada suhu bilik $\left(28^{\circ} \mathrm{C}\right)$. Sampel dituras menggunakan sistem pam vakum dan dicairkan hingga $100 \mathrm{~mL}$. Sebanyak $10 \mathrm{~mL}$ sampel diperlukan untuk analisis logam berat (McLaughlin et al. 2000). 


\section{RENDAMAN SEJUK}

Sebanyak $0.5 \mathrm{~g}$ sampel ditimbang dan dimasukkan ke dalam kelalang isi padu $100 \mathrm{~mL}$. Sampel direndam dalam $5 \mathrm{~mL}$ asid nitrik pekat selama 36 jam pada suhu bilik (28 ${ }^{\circ} \mathrm{C}$ ). Sampel kemudiannya dituras menggunakan sistem pam vakum dan dicairkan hingga $100 \mathrm{~mL}$. Sebanyak $10 \mathrm{~mL}$ sampel diperlukan untuk analisis logam berat (Kleckerová \& Dočekalová 2014).

\section{TEKNIK PENGERINGAN ABU}

Sebanyak $200 \mathrm{~g}$ sampel dikeringkan di dalam relau semalaman pada suhu $70^{\circ} \mathrm{C}$. Sampel kemudian diletakkan dalam mangkuk pijar untuk dibakar di dalam relau pembakaran selama 24 jam pada suhu $500{ }^{\circ} \mathrm{C}$. Sampel bertukar menjadi abu selepas pembakaran. Seterusnya, $0.5 \mathrm{~g}$ daripada abu sampel tersebut ditimbang dan dimasukkan ke dalam bikar bersama $1 \mathrm{~mL}$ asid nitrik pekat. Larutan tersebut dipanaskan sehingga mendidih selama 10 minit dan dibiarkan sejuk pada suhu bilik (28 $\left.{ }^{\circ} \mathrm{C}\right)$. Kemudian, larutan itu dituras menggunakan sistem pam vakum. Sampel untuk analisis disediakan dengan mencairkan hasil turasan hingga $100 \mathrm{~mL}$. Sebanyak 10 $\mathrm{mL}$ sampel diperlukan untuk analisis logam berat (Kaya \& Yaman 2012).

\section{ULTRASONIK}

Kaedah ultrasonik dijalankan menggunakan bekas air ultrasonik dengan tetapan kuasa $300 \mathrm{~W}$. Sebanyak 0.5 g sampel dan $5 \mathrm{~mL}$ asid nitrik pekat dicampurkan ke dalam kelalang kon $100 \mathrm{~mL}$. Sampel didedahkan dengan ultrasonik pada suhu $25^{\circ} \mathrm{C}$ selama 30 minit. Selepas itu, sampel dituras menggunakan sistem pam vakum dan dicairkan hingga $100 \mathrm{~mL} .10 \mathrm{~mL}$ sampel diperlukan untuk analisis logam berat (Arain et al. 2008).

\section{ANALISIS LOGAM BERAT}

Kandungan logam berat dikuantifikasi menggunakan instrumen spektrofotometer pancaran plasma-gandingan aruhan (ICP-OES)(Optima 4300 DV, Perkin-Elmer). Kalibrasi alat dijalankan dengan mengukur kepekatan larutan piawai unsur yang ingin dikesan seperti $\mathrm{Al}, \mathrm{As}$, $\mathrm{Cr}, \mathrm{Cu}, \mathrm{Fe}, \mathrm{Mn}, \mathrm{Ni}, \mathrm{Pb}$ dan $\mathrm{Zn}$, Setiap larutan piawai diketahui kepekatannya dan dilarutkan dalam beberapa siri kepekatan bersama-sama 2\% asid nitrik. Bagi setiap unsur piawai dan satu larutan kosong-nilai, satu lengkung kalibrasi bergaris lurus dengan nilai pekali $r \geq 0.95$ perlu dicapai supaya kalibrasi alat diterima dan analisis sampel boleh diteruskan.
Data analisis logam berat digunakan untuk pengiraan faktor pengayaan (EF) dan faktor biokepekekatan (BCF). Sampel mestilah dalam keadaan cecair. Larutan sampel juga perlu dicairkan terlebih dahulu supaya kandungan asid nitrik $\leq 5 \%$. Jumlah minimum sampel diperlukan ialah $10 \mathrm{~mL}$ yang disediakan di dalam tabung uji bertutup $12 \mathrm{~mL}$. Tempoh analisis ialah 3 minit per sampel (operasi secara automatik). Semua sampel dianalisis dua kali dan bacaan purata kepekatan dan sisihan piawai diambil. Bacaan output daripada alat adalah dalam unit ppm (mg/L) dan ditukarkan menjadi unit $\mathrm{mg} / \mathrm{kg}$ bagi menghitung kepekatan unsur dengan mengambil kira faktor pengiraan (calculating factor) penyediaan sampel berdasarkan formula berikut:

Kepekatan unsur $(m g / k g)=$ Output,ppm $(m g / L) \times \frac{\text { isi padu larutan }(m L)}{\text { berat } \operatorname{sampel}(g)}(1)$

\section{FAKTOR PENGAYAAN (EF)}

Faktor pengayaan (Enrichment factor, EF) adalah berguna untuk mengetahui punca unsur surih yang dikesan dalam sampel sama ada datang daripada alam semula jadi atau berpunca daripada aktiviti manusia (antropogenik). Pengiraan nilai EF adalah berdasarkan nilai relatif kuantiti unsur (M) dalam sampel terhadap kuantiti aluminium (Al) dalam sampel yang dinisbahkan dengan kuantiti unsur (M) piawai (dalam kerak bumi) terhadap kuantiti Al piawai (dalam kerak bumi). Secara formulanya,

$$
\text { Faktor pengayaan, } E F=\frac{\left(\frac{M}{A l}\right) \text { sampel }}{\left(\frac{M}{A l}\right) \text { piawai }}
$$

Rujukan nilai piawai bagi unsur-unsur dalam kerak bumi diperoleh daripada Wedepohl (1995) yang sering digunakan oleh penyelidik-penyelidik yang menjalankan kajian di kawasan tropika khususnya di Malaysia.

\section{FAKTOR BIOKEPEKATAN (BCF) UNSUR DARI TANAH}

Faktor biokepekatan (BCF) unsur dari tanah merupakan nisbah kepekatan logam (C) dalam sampel pokok terhadap kepekatan logam tersebut dalam sampel tanah. Nilai ini menunjukkan kemajuan pengumpulan logam dalam setiap sampel daripada tanah. Nilai BCF melebihi 1 bermaksud kapasiti penyerapan logam yang tinggi daripada tanah ke tisu tumbuhan atau penyerapan logam secara terus daripada persekitaran (Kaewtubtim et al. 2016). Pengiraan BCF adalah berdasarkan formula berikut: 
Faktor biokepekatan $(B C F)=\frac{C_{\text {sampel }}}{C_{\text {tanah }}}$

\section{HASIL KAJIAN DAN PERBINCANGAN}

Terdapat lima kaedah pencernaan asid (mikrogelombang, pencernaan asid panas, pengeringan abu, rendaman sejuk dan ultrasonik) dibandingkan bagi mengetahui kaedah yang terbaik untuk mengekstrak logam berat dalam setiap sampel. Pemilihan kaedah pencernaan asid yang sesuai dengan sampel perlu dilakukan disebabkan beberapa faktor seperti penghasilan ekstrak logam berat yang maksimum daripada sampel, penjimatan masa dan bahan kimia serta penyediaan radas dan kerja makmal (Ahmed 2009; Hseu 2014; Trusheva et al. 2007). Selain itu, kuantifikasi logam berat yang maksimum adalah penting bagi mengetahui nilai sebenar faktor pengayaan (EF) (Othman et al. 2015) dan faktor biokepekatan (BCF) (Sharma et al. 2018), masing-masing bertujuan untuk mengenal pasti punca kehadiran logam berat dan kebolehan biomonitor spesies yang dipilih. Jadual 1 menunjukkan hasil analisis logam berat dalam setiap sampel mengikut kaedah tertentu.

JADUAL 1. Perbandingan hasil kuantifikasi logam berat mengikut kaedah pengesktrakan

\begin{tabular}{|c|c|c|c|c|c|c|c|c|c|c|c|c|c|c|c|c|c|c|c|c|}
\hline \multirow{3}{*}{$\begin{array}{c}\text { Logam } \\
\text { berat }\end{array}$} & \multicolumn{20}{|c|}{ Sampel } \\
\hline & \multicolumn{5}{|c|}{ Tanah } & \multicolumn{5}{|c|}{ Daun } & \multicolumn{5}{|c|}{ Kulit kayu } & \multicolumn{5}{|c|}{ Lateks } \\
\hline & MG & PA & PB & RS & US & MG & PA & PB & RS & US & MG & PA & PB & RS & US & MG & PA & PB & RS & US \\
\hline As & 0.4 & 10.4 & ud & ud & ud & ud & ud & ud & ud & ud & ud & ud & 0.6 & ud & ud & ud & ud & ud & ud & ud \\
\hline $\mathrm{Cr}$ & ud & 1.6 & ud & ud & ud & 0.6 & ud & 0.6 & 0.8 & ud & ud & ud & ud & ud & ud & ud & ud & ud & ud & ud \\
\hline $\mathrm{Cu}$ & ud & 25.4 & 35.8 & ud & ud & 26.2 & 22 & 14.4 & 27.2 & 13.4 & 27.4 & 22.4 & ud & 20 & 6.6 & 19.4 & 14 & 20.8 & 21.6 & ud \\
\hline $\mathrm{Fe}$ & 284.2 & 1085.4 & 777 & 573.4 & 25.2 & 106.2 & 50 & 103 & 123 & ud & 301.4 & 56.4 & 46 & 257.2 & 44.8 & 32.8 & 50.6 & 35.4 & 30.4 & ud \\
\hline $\mathrm{Mn}$ & 3 & 22.2 & 36.8 & 5.8 & ud & 574.6 & 117.4 & 571.2 & 484.4 & 155 & 188.2 & 41.2 & 118.4 & 133.6 & ud & 9.8 & 13 & 11.4 & 17.8 & 17.4 \\
\hline $\mathrm{Ni}$ & ud & ud & ud & ud & ud & ud & ud & ud & ud & ud & ud & ud & ud & ud & ud & ud & ud & ud & ud & ud \\
\hline $\mathrm{Pb}$ & ud & 8.2 & 4.2 & ud & ud & 4.6 & 2.6 & 2 & 4.8 & ud & 6.4 & 2.4 & 2.6 & 5.2 & ud & 1.6 & 2.2 & ud & ud & ud \\
\hline $\mathrm{Zn}$ & ud & 32 & 322.4 & 10.4 & ud & 55.2 & 49.8 & 28.4 & 78 & ud & 76.8 & 79 & 24.2 & 88.6 & 16 & 40.2 & 55.8 & 117.8 & 16.4 & ud \\
\hline $\begin{array}{c}\text { Jumlah, } \\
\mathrm{mg} / \mathrm{kg}\end{array}$ & 287.6 & 1185.2 & 1176.2 & 589.6 & 25.2 & 767.4 & 241.8 & 719.6 & 718.2 & 168.4 & 600.2 & 201.4 & 191.8 & 504.6 & 67.4 & 103.8 & 135.6 & 185.4 & 86.2 & 17.4 \\
\hline
\end{tabular}

*ud $=$ tidak dikesan

** $\mathrm{MG}=$ mikrogelombang, $\mathrm{PA}=$ pencernaan asid panas, $\mathrm{PB}=$ pengeringan abu, $\mathrm{RS}=$ rendaman sejuk, $\mathrm{US}=$ ultrasonik

\section{SAMPEL TANAH}

Pencernaan asid panas merupakan kaedah pengekstrakan logam berat paling banyak dalam sampel tanah $(1185.2$ $\mathrm{mg} / \mathrm{kg})$, diikuti kaedah pengeringan abu (1176.2 $\mathrm{mg} / \mathrm{kg})$, rendaman sejuk $(589.6 \mathrm{mg} / \mathrm{kg})$, pencernaan mikrogelombang $(287.6 \mathrm{mg} / \mathrm{kg})$ dan kaedah ultrasonik (25.2 $\mathrm{mg} / \mathrm{kg}$ ). Pencernaan menggunakan asid yang panas dan pengeringan abu merupakan dua kaedah yang menghasilkan ekstrak logam berat yang tinggi. Hal ini disebabkan oleh sifat fizikokimia tanah yang memerlukan haba yang tinggi bagi memutuskan ikatan fizikal antara logam berat dengan silika atau sebatian dalam tanah (Almasoud et al. 2015). Bagi kaedah ultrasonik, hanya Fe dan Mn yang berjaya diekstrak. Saiz zarah Fe dan Mn yang lebih kecil berbanding logam berat lain memudahkannya diekstrak berbanding logam berat lain melalui kaedah ini (Leong et al. 2013). Pencernaan asid panas yang menggunakan radas ringkas dan masa yang singkat (15 minit) dipilih bagi mencernakan sampel tanah berbanding pengeringan abu yang memerlukan penyediaan radas dan kerja makmal yang lebih rumit. 
SAMPEL DAUN

Berdasarkan analisis ICP-OES, pencernaan mikrogelombang mengekstrak logam berat dengan kepekatan tertinggi dalam sampel daun (767.4 mg/ $\mathrm{kg}$ ), diikuti pengeringan abu $(719.6 \mathrm{mg} / \mathrm{kg})$, rendaman sejuk $(718.2 \mathrm{mg} / \mathrm{kg})$, pencernaan asid panas $(241.8$ $\mathrm{mg} / \mathrm{kg}$ ) dan akhir sekali kaedah ultrasonik (168.4 mg/ $\mathrm{kg})$. Suhu pencernaan yang tinggi semasa kaedah mikrogelombang membantu dalam memusnahkan matrik organik sampel daun yang mengandungi logam berat bagi memudahkan pencernaannya (Chen et al. 2018). Walaupun rendaman sejuk dan kaedah ultrasonik dijalankan pada suhu bilik $\left(28^{\circ} \mathrm{C}\right)$, terdapat perbezaan yang ketara dalam hasil ekstrak kedua-dua kaedah. Masa rendaman yang lebih lama (72 jam) telah menghasilkan ekstrak logam berat yang lebih banyak kerana proses pencernaan logam berat lebih banyak berlaku apabila semakin banyak ikatan logam berat dengan matriks daun diputuskan. Namun, atas faktor penjimatan masa dan hasil ekstrak, kaedah mikrogelombang adalah yang terbaik bagi pencernaan sampel daun.

\section{SAMPEL KULIT KAYU}

Trend pencernaan logam berat dalam sampel kulit kayu adalah lebih kurang sama dengan pencernaan sampel daun. Walau bagaimanapun, kandungan logam berat dalam sampel kulit kayu didapati kurang daripada sampel daun. Ciri lipofilik kulit kayu yang lebih tertarik terhadap sebatian organik dan jirim meruap sebagaimana yang dikaji oleh He et al. (2014) menerangkan keadaan kandungan logam berat yang kurang dalam kulit kayu berbanding daun. Dogan et al. (2014) melaporkan penemuan yang sama iaitu pengumpulan logam berat yang lebih tinggi dalam sampel daun berbanding kulit kayu bagi spesies Juglans regia. Kaedah mikrogelombang menghasilkan ekstrak logam berat terbanyak, diikuti rendaman sejuk, pencernaan asid panas, pengeringan abu dan kaedah ultrasonik, masing-masing dengan nilai $600.2 \mathrm{mg} / \mathrm{kg}, 504.6 \mathrm{mg} / \mathrm{kg}, 201.4 \mathrm{mg} / \mathrm{kg}, 191.8 \mathrm{mg} / \mathrm{kg}$ dan $67.4 \mathrm{mg} / \mathrm{kg}$.

\section{SAMPEL LATEKS}

Bagi analisis logam berat dalam sampel lateks, kaedah pengeringan abu menghasilkan ekstrak logam berat tertinggi $(185.4 \mathrm{mg} / \mathrm{kg})$, diikuti pencernaan asid panas (135.6 mg/kg), pencernaan mikrogelombang (103.8 mg/ $\mathrm{kg})$, rendaman sejuk $(86.2 \mathrm{mg} / \mathrm{kg})$ dan kaedah ultrasonik $(17.4 \mathrm{mg} / \mathrm{kg})$. Komposisi kimia dan fizikal lateks yang terdiri daripada matriks dalam fasa getah menyukarkan pencernaan logam berat dilakukan oleh sesetengah kaedah. Pengeringan abu yang memusnahkan semua matriks getah menjadi serbuk abu telah memudahkan tindak balas pencernaan antara asid dengan sampel yang mempunyai luas permukaan yang besar (Haque et al. 2020).

\section{ANALISIS LOGAM BERAT}

Berdasarkan perbandingan kaedah pengekstrakan logam berat, setiap sampel didapati memerlukan kaedah pengekstrakan yang tertentu untuk menghasilkan bacaan ekstrak logam berat yang maksimum. Sebagai contoh, sampel tanah; pencernaan asid panas, sampel daun; pencernaan asid gelombang mikro, sampel kulit kayu; pencernaan asid gelombang mikro dan sampel lateks; teknik pengeringan abu. Seterusnya, data logam berat maksimum bagi setiap sampel tersebut telah digunakan untuk menghitung nilai EF dan BCF sebagaimana yang ditunjukkan dalam Jadual 2. Berdasarkan analisis EF, sampel tanah didapati mengalami pengayaan logam berat $\mathrm{As}, \mathrm{Cu}, \mathrm{Pb}$ dan $\mathrm{Zn}$. Logam berat $\mathrm{Cr}$, Fe dan $\mathrm{Mn}$ mempunyai nilai EF $<1$ yang menunjukkan logam berat tersebut datang daripada alam semula jadi. Tiada unsur Cd dikesan dalam semua kaedah pencernaan menunjukkan bahawa kawasan kajian tidak didedahkan dengan bahan kimia yang mengandungi $\mathrm{Cd}$.

Kehadiran logam berat $\mathrm{Cr}, \mathrm{Cu}, \mathrm{Fe}, \mathrm{Mn}, \mathrm{Pb}$ dan Zn dalam sampel daun dengan nilai $\mathrm{EF}>1$ dijangka berpunca daripada aktiviti manusia terutamanya asap kenderaan. Kandungan Mn adalah yang paling tinggi dalam daun $(574.6 \mathrm{mg} / \mathrm{kg})$ disebabkan peranannya dalam aktiviti fotosintesis dan fisiologi yang berlaku dalam daun. Namun, nilai EF bagi Mn yang tinggi (762.3) menandakan tahap pencemaran Mn yang turut datang daripada aktiviti manusia.

Nilai EF bagi $\mathrm{Cu}, \mathrm{Fe}, \mathrm{Mn}, \mathrm{Pb}$ dan $\mathrm{Zn}$ dalam sampel kulit kayu yang melebihi 1 menandakan pengayaan logam berat tersebut. Kandungan Fe adalah yang tertinggi $(300 \mathrm{mg} / \mathrm{kg}$ ) dalam sampel ini. Al-Alawi et al. (2007) turut melaporkan kepekatan Fe yang tertinggi dalam kulit kayu pokok pine Aleppo yang berpunca daripada pelepasan asap kenderaan dan pembakaran bahan api.

Kebanyakan logam berat sudah disimpan dalam daun dan kulit kayu disebabkan keadaan fizikalnya yang terdedah kepada atmosfera, justeru menerangkan kandungan logam berat dalam setiap sampel adalah dalam trend daun $>$ kulit kayu $>$ lateks. Lateks merupakan hasil sekunder pokok getah yang mengalami metabolisme 
sebelum disimpan dalam kulit kayu dalam bentuk sitoplasma. Namun, kehadiran beberapa logam berat $(\mathrm{Cu}$, $\mathrm{Fe}, \mathrm{Mn}, \mathrm{Zn}$ ) yang terdapat dalam lateks memberikannya potensi sebagai sampel biomonitor baharu berbanding sampel biomonitor daun dan kulit kayu yang tipikal.

Sementara itu, nilai BCF melebihi 1 bagi logam berat $\mathrm{Cu}$ dan Mn bagi sampel daun dan kulit kayu serta $\mathrm{Zn}$ bagi sampel kulit kayu dan sampel lateks menunjukkan logam tersebut telah diangkut dari sampel tanah ke tisu tumbuhan melalui sistem akar ataupun atmosfera.

JADUAL 2. Analisis kepekatan logam berat

\begin{tabular}{|c|c|c|c|c|c|c|c|c|c|c|c|}
\hline \multirow{3}{*}{ Logam berat } & \multicolumn{11}{|c|}{ Sampel } \\
\hline & \multicolumn{2}{|c|}{ Tanah } & \multicolumn{3}{|c|}{ Daun } & \multicolumn{3}{|c|}{ Kulit kayu } & \multicolumn{3}{|c|}{ Lateks } \\
\hline & $\begin{array}{c}\text { Kepekatan, } \\
\mathrm{mg} / \mathrm{kg}\end{array}$ & $\mathrm{EF}$ & $\begin{array}{c}\text { Kepekatan, } \\
\mathrm{mg} / \mathrm{kg}\end{array}$ & $\mathrm{EF}$ & $\mathrm{BCF}$ & $\begin{array}{c}\text { Kepekatan, } \\
\mathrm{mg} / \mathrm{kg}\end{array}$ & $\mathrm{EF}$ & $\mathrm{BCF}$ & $\begin{array}{c}\text { Kepekatan, } \\
\mathrm{mg} / \mathrm{kg}\end{array}$ & EF & $\mathrm{BCF}$ \\
\hline As & 10.4 & 69.9 & ud & $\mathrm{n} / \mathrm{a}$ & $\mathrm{n} / \mathrm{a}$ & ud & $\mathrm{n} / \mathrm{a}$ & $\mathrm{n} / \mathrm{a}$ & ud & $\mathrm{n} / \mathrm{a}$ & $\mathrm{n} / \mathrm{a}$ \\
\hline $\mathrm{Cr}$ & 1.6 & 0.5 & 0.6 & 13.6 & 0.4 & ud & $\mathrm{n} / \mathrm{a}$ & $\mathrm{n} / \mathrm{a}$ & ud & $\mathrm{n} / \mathrm{a}$ & $\mathrm{n} / \mathrm{a}$ \\
\hline $\mathrm{Cu}$ & 25.4 & 7.3 & 26.2 & 595.9 & 1.03 & 27.4 & 243.8 & 1.08 & 20.8 & 353.9 & 0.8 \\
\hline $\mathrm{Fe}$ & 1085.4 & 0.3 & 106.2 & 2.4 & 0.1 & 301.4 & 2.7 & 0.3 & 35.4 & 0.6 & 0.03 \\
\hline $\mathrm{Mn}$ & 22.2 & 0.4 & 574.6 & 762.3 & 25.9 & 188.2 & 97.7 & 8.5 & 11.4 & 11.3 & 0.5 \\
\hline $\mathrm{Pb}$ & 8.2 & 4.1 & 4.6 & 183.1 & 0.5 & 6.4 & 99.6 & 0.8 & ud & $\mathrm{n} / \mathrm{a}$ & $\mathrm{n} / \mathrm{a}$ \\
\hline $\mathrm{Zn}$ & 32 & 4.2 & 55.2 & 61.9 & 0.2 & 76.8 & 310.6 & 2.4 & 117.8 & 911.1 & 3.7 \\
\hline
\end{tabular}

*ud = tidak dikesan, $\mathrm{n} / \mathrm{a}=$ tiada nilai untuk dihitung kerana tiada unsur logam tersebut dikesan

$* *[\mathrm{Al}]$ untuk pengiraan $\mathrm{EF} ; \operatorname{tanah}=7968$, daun $=101$, kulit $\mathrm{kayu}=258.2$, lateks $=135$

\section{KESIMPULAN}

Lima prosedur pengekstrakan telah dijalankan bagi pencernaan logam berat dalam sampel tanah dan bahagian tumbuhan Hevea brasilinesis seperti daun, kulit kayu dan lateks di Bentong, Pahang, Malaysia. Kami mendapati bahawa setiap sampel memerlukan kaedah pencernaan mereka sendiri. Pencernaan asid panas ialah prosedur yang paling sesuai untuk pencernaan logam berat bagi sampel tanah $(1185.2 \mathrm{mg} / \mathrm{kg})$. Sementara itu, pencernaan asid gelombang mikro mengekstrak logam paling banyak dalam kedua-dua sampel daun (767.4 $\mathrm{mg} / \mathrm{kg})$ dan kulit kayu $(600.2 \mathrm{mg} / \mathrm{kg})$, manakala teknik pengeringan abu mengekstrak jumlah logam berat tertinggi dalam sampel lateks $(185.4 \mathrm{mg} / \mathrm{kg})$. Menariknya, ketigatiga kaedah tersebut (pencernaan asid panas, pencernaan asid gelombang mikro, teknik pengeringan abu) adalah lebih praktikal daripada segi pengurusan masa dan kerja makmal berbanding kaedah lain (rendaman sejuk dan pengekstrakan ultrasonik). Melalui data analisis logam berat yang maksimum ini, pengiraan nilai EF dan BCF mencatatkan tahap serapan logam berat yang lebih tepat sebagai petunjuk awal terhadap kemampuan Hevea brasiliensis menjadi biomonitor kandungan logam berat di persekitaran. Untuk kajian akan datang, penyerapan bahan pencemar oleh Hevea brasiliensis selain logam berat seperti polisiklik aromatik hidrokarbon (PAH), ozon atau sulfur dioksida boleh dijalankan.

\section{PENGHARGAAN}

Kami ingin berterima kasih kepada Kementerian 
Pengajian Tinggi Malaysia dan Universiti Kebangsaan Malaysia melalui tajaan geran penyelidikan FRGS/1/2016/STG01/UKM/02/4 dan GUP-2017-004.

\section{RUJUKAN}

Ahmed, S.A. 2009. Extraction of NOx and determination of nitrate by acid reduction in water, soil, excreta, feed, vegetables and plant materials. Journal of Applied Sciences and Environmental Management 13(3): 57-63.

Al-Alawi, M.T.M., Batarseh, M.I., Carreras, H., Alawi, M., Jiries, A. \& Charlesworth, S.M. 2007. Aleppo pine bark as a biomonitor of atmospheric pollution in the arid environment of Jordan. CLEAN-Soil, Air, Water 35(5): 438-443.

Almasoud, F.I., Usman, A.R. \& Al-Farraj, A.S. 2015. Heavy metals in the soils of the Arabian Gulf coast affected by industrial activities: Analysis and assessment using enrichment factor and multivariate analysis. Arabian Journal of Geosciences 8(3): 1691-1703.

Arain, M.B., Kazi, T.G., Jamali, M.K., Jalbani, N., Afridi, H.I. \& Baig, J.A. 2008. Speciation of heavy metals in sediment by conventional, ultrasound and microwave assisted single extraction methods: A comparison with modified sequential extraction procedure. Journal of Hazardous Materials 154(1-3): 998-1006.

Ayaz, M., Junaid, M., Subhan, F., Ullah, F., Sadiq, A., Ahmad, S. \& Imran, M. 2014. Heavy metals analysis, phytochemical, phytotoxic and anthelmintic investigations of crude methanolic extract, subsequent fractions and crude saponins from Polygonum hydropiper L. BMC Complementary and Alternative Medicine 14(1): 465.

Chibuike, G.U. \& Obiora, S.C. 2014. Heavy metal polluted soils: Effect on plants and bioremediation methods. Applied and Environmental Soil Science doi:10.1155/2014/752708.

Chen, L., Shen, M., Ma, A. \& Han, W. 2018. Investigation of trace element content in the seeds, pulp, and peel of mashui oranges using microwave digestion and ICP-MS analysis. Biological Trace Element Research 182(1): 152-158.

de Mello, M.L., Fialho, L.L., Pirola, C. \& Nóbrega, J.A. 2020. Evaluation of recycle and reuse of nitric acid from sample digests by sub-boiling distillation. Microchemical Journal 157: 105080.

Dogan, Y., Unver, M.C., Ugulu, I., Calis, M. \& Durkan, N. 2014. Heavy metal accumulation in the bark and leaves of Juglans regia planted in Artvin City, Turkey. Biotechnology, Biotechnological Equipment 28(4): 643649.

Factory, T., Gitet, H., Hilawie, M. \& Muuz, M. 2016. Bioaccumulation of heavy metals in crop plants grown. Environmental Monitoring and Assessment doi:10.1007/ s10661-016-5511-0.

Haque, E., Pahlevani, F., Gorjizadeh, N., Hossain, R. \& Sahajwalla, V. 2020. Thermal transformation of end-oflife latex to valuable materials. Journal of Composites
Science 4(4): 166.

He, C., Jin, J., Wang, Y., Ma, Z., He, S. \& Li, M. 2014. Polybrominated diphenyl ethers, dechlorane plus, and polychlorinated biphenyls in tree bark near the upper Yellow River, China. Environmental Toxicology and Chemistry 33(8): 1732-1738.

Hseu, Z. 2004. Evaluating heavy metal contents in nine composts using four digestion methods. Bioresource Technology 95(1): 53-59.

Kaewtubtim, P., Meeinkuirt, W., Seepom, S. \& Pichtel, J. 2016. Heavy metal phytoremediation potential of plant species in a mangrove ecosystem in Pattani Bay, Thailand. Applied Ecology and Environmental Research 14(1): 367-382.

Kaya, G. \& Yaman, M. 2012. Determination of trace metals in plant leaves as biomonitor of pollution extent by a sensitive STAT-AAS method. Instrumentation Science \& Technology 40(1): 61-74.

Kleckerová, A. \& Dočekalová, H. 2014. Dandelion plants as a biomonitor of urban area contamination by heavy metals. International Journal of Environmental Research 8(1): 157-164.

Leong, T., Johansson, L., Juliano, P., McArthur, S.L. \& Manasseh, R. 2013. Ultrasonic separation of particulate fluids in small and large scale systems: A review. Industrial \& Engineering Chemistry Research 52(47): $16555-16576$

Li, Z., Ma, Z., van der Kuijp, T.J., Yuan, Z. \& Huang, L. 2014. A review of soil heavy metal pollution from mines in China: Pollution and health risk assessment. Science of The Total Environment 468: 843-853.

Liu, T., Liu, B. \& Zhang, W. 2014. Nutrients and heavy metals in biochar produced by sewage sludge pyrolysis: Its application in soil amendment. Polymer Journal of Environmental Studies 23(1): 271-275.

McLaughlin, M.J., Zarcinas, B.A., Stevens, D.P. \& Cook, N. 2000. Soil testing for heavy metals. Communications in Soil Science and Plant Analysis 31(11-14): 1661-1700.

Melo, V.F., Batista, A.H., Gilkes, R.J. \& Rate, A.W. 2016. Relationship between heavy metals and minerals extracted from soil clay by standard and novel acid extraction procedures. Environmental Monitoring and Assessment 188(12): 668 .

Othman, M., Latif, M.T. \& Mohamed, A.F. 2015. The PM 10 compositions, sources and health risks assessment in mechanically ventilated office buildings in an urban environment. Air Quality, Atmosphere \& Health 9(16): 597-612.

Rajkumar, M., Sandhya, S., Prasad, M.N.V. \& Freitas, H. 2012. Perspectives of plant-associated microbes in heavy metal phytoremediation. Biotechnology Advances 30(6): 15621574.

Rashid, H., Fardous, Z., Chowdhury, M.A.Z. \& Alam, K. 2016. Determination of heavy metals in the soils of tea plantations and in fresh and processed tea leaves: An 
evaluation of six digestion methods. Chemistry Central Journal 10(7): 1-13.

Rauret, G. 1998. Extraction procedures for the determination of heavy metals in contaminated soil and sediment. Talanta 46(3): 449-455.

Ricci, B.C., Ferreira, C.D., Marques, L.S., Martins, S.S. \& Amaral, M.C.S. 2016. Assessment of nanofiltration and reverse osmosis potentialities to recover metals, sulfuric acid, and recycled water from acid gold mining effluent. Water Science and Technology 74(2): 367-374.

Selvi, A., Rajasekar, A., Theerthagiri, J., Ananthaselvam, A., Sathishkumar, K., Madhavan, J. \& Rahman, P.K. 2019. Integrated remediation processes toward heavy metal removal/recovery from various environments-a review. Frontiers in Environmental Science 7: 66.

Sharma, S., Nagpal, A.K. \& Kaur, I. 2018. Heavy metal contamination in soil, food crops and associated health risks for residents of Ropar wetland, Punjab, India and its environs. Food Chemistry 255: 15-22.

Simpson, T. 2017. Field Sampling Quality Control. U.S Environmental Protection Agency, Georgia:.SSD Operating Procedure. SESDRPC-011-R5.

Singh, J., Janardhan, K., Chang, Y., Kang, S. \& Yang, J. 2016. A novel reutilization method for automobile shredder residue as an adsorbent for the removal of methylene blue: Mechanisms and heavy metal recovery using an ultrasonically assisted acid. Process Safety and Environmental Protection 99: 88-97.

Thakur, S., Singh, L., Wahid, Z.A., Siddiqui, M.F., Atnaw, S.M. \& Din, M.F.M. 2016. Plant-driven removal of heavy metals from soil: Uptake, translocation, tolerance mechanism, challenges, and future perspectives. Environmental Monitoring and Assessment 188(4): 206.

Trusheva, B., Trunkova, D. \& Bankova, V. 2007. Different extraction methods of biologically active components from propolis: A preliminary study. Chemistry Central Journal 1(1): 13 .

Wedepohl, K.H. 1995. The composition of the continental crust. Geochimica et Cosmochimica Acta 59(7): 1217-1232.

Wei, L., Zhang, M., Wei, S., Zhang, J., Wang, C. \& Liao,
W. 2020. Roles of nitric oxide in heavy metal stress in plants: Cross-talk with phytohormones and protein S-nitrosylation. Environmental Pollution 259: 113943.

Witters, N., Mendelsohn, R., Passel, S. Van, Slycken, S. Van, Weyens, N. \& Schreurs, E. 2011. Phytoremediation, a sustainable remediation technology? II: Economic assessment of $\mathrm{CO}_{2}$ abatement through the use of phytoremediation crops for renewable energy production. Biomass and Bioenergy 39: 470-477.

Yilmaz, V., Arslan, Z., Hazer, O. \& Yilmaz, H. 2014. Selective solid phase extraction of copper using a new $\mathrm{Cu}(\mathrm{II})$ imprinted polymer and determination by inductively coupled plasma optical emission spectroscopy (ICP-OES). Microchemical Journal 114(Supplement C): 65-72.

Zimmerman, A.J. \& Weindorf, D.C. 2010. Heavy metal and trace metal analysis in soil by sequential extraction: A review of procedures. International Journal of Analytical Chemistry doi:10.1155/2010/387803.

Muhammad Jefri Mohd Yusof \& Siti Fairus Mohd Yusoff** Jabatan Sains Kimia

Fakulti Sains dan Teknologi

Universiti Kebangsaan Malaysia

43600 UKM Bangi, Selangor Darul Ehsan

Malaysia

Mohd Talib Latif

Jabatan Sains Bumi dan Persekitaran

Fakulti Sains dan Teknologi

Universiti Kebangsaan Malaysia

43600 UKM Bangi, Selangor Darul Ehsan

Malaysia

*Pengarang untuk surat-menyurat; email: sitifairus@ukm.edu.my

Diserahkan: 26 November 2020

Diterima: 17 Januari 2021 